Го Ю. Психологізм прозових творів С. Гуцала, опублікованих у журналі "Дніпро" ...

УДК 821.161.82-3

DOI https://doi.org/10.24919/2308-4863/34-2-14

Юаньпен ГО,

orcid.org/0000-0002-4525-3218

аспірант кафедри історії української літератури, теорії літератури та літературної творчості

Інституту філологї

Київського національного університету імені Тараса Шевченка

(Київ, Україна) andri13855@gmail.com

\title{
ПСИХОЛОГІЗМ ПРОЗОВИХ ТВОРІВ Є. ГУЦАЛА, ОПУБЛІКОВАНИХ У ЖУРНАЛІ «ДНІПРО» ВСЕРЕДИНІ ХХ СТ.
}

У статті здійснено огляд прозових творів С. Гуцала, опублікованих всередині минулого століття в журналі «Дніпро», розглянуто їхню тематику, проблематику й образну систему та проаналізовано особливості ідіостилю прозаїка-дебютанта, який творив в умовах жорстких шаблонів і догм соиреалізму.

Встановлено, що автор всупереч «сочіальному замовленню» влади у своїй лірико-романтичній, а згодом $i$ реалістичній прозі подав правдиві картини життя народу за часів радянського режиму, особливо під час і після війни, не оминаючи увагою трагічної теми братовбивства, акцентував увагу на екзистениії людської душі, глибоко розкриваючи внутрішній світ сучасної йому людини, показав розруху, голод і безвихідність становища тогочасних людей, відстоював загальнолюдські иінності. Крізь внутрішній стан героїв, їхні почуття, настрої і ставлення до різних подій можна краще усвідомити пріоритети й принципи самого письменника-шістдесятника.

Визначено, щу домінантними рисами ранніх прозових творів письменника є глибокий психологізм, ліризм, численні алюзї, дегероїзачія прози, контекстуальна деталь, лаконізм оповіді. Автор вдавався й до персоніфікації та імпресіоністичних замальовок, коли відтворював різні події й настрої героїв творів у тісному зв'язку з явищами природи, яка є органічною частиною життя людей. Простежено, що особливу увагу автор приділяє образам дітей, крізь свідомість яких можна по-іншому подивитися на світ, спотворений тоталітарним режимом, ненавистю і жорстокістю.

Деякі критики, зокрема й ті, які жили за межами Радянського Союзу (Л. Сеник, І. Зуб, Б. Кравців та інші), підтримували С. Гуцала, називаючи його «зачинателем нової модерної прози», інші ж засуджували творчість мития й звинувачували прозаїка в «неясності художнього задуму» (Л. Бахаєва), асоиіальності творів (В. Андрієнко).

Ключові слова: прозаӥк-шістдесятник, психологізм, персоніфікація, алюзї, контекстуальна деталь, сочреалізм, журнал «Дніпро».

Yuanpeng GUO, orcid.org/0000-0002-4525-3218 Graduate Student at the Department of Ukrainian Literature History, Theory of Literature and Literary Art Institute of Philology of Taras Shevchenko National University of Kyiv (Kyiv, Ukraine) andri13855@gmail.com

\section{PSYCHOLOGISM OF PROSE WORKS BY E. GUTSALO, PUBLISHED IN THE MAGAZINE “DNIPRO” IN THE MIDDLE OF THE TWENTIETH CENTURY}

The article reviews the prose works of E. Gutsalo, published in the middle of the last century in the magazine "Dnipro" considers their themes, issues, and image system and analyzes the idiosyncrasies of the debutant prose writer, who created in the conditions of rigid patterns and dogmas of social realism.

It is established that the author, contrary to the "social order" of power in his lyrical-romantic, and later realistic prose gave true pictures of people's lives during the Soviet regime, especially during and after the war, not avoiding the tragic theme of fratricide, focused on human existence soul, deeply revealing the inner world of his contemporary man, showed the devastation, hunger and hopelessness of the people of that time, defended universal values. Through the inner state of the characters, their feelings, moods and attitudes to various events, you can better understand the priorities and principles of the writer of the sixties.

It is determined that the dominant features of the writer's early prose works are deep psychologism, lyricism, numerous allusions, degeneration of prose, contextual detail, laconic narrative. The author also resorted to personification and impressionistic sketches, recreating various events and moods of the heroes of the works in close connection with the 
phenomena of nature, which is an organic part of human life. It is observed that the author pays special attention to the images of children, through whose consciousness it is possible to look differently at the world distorted by the totalitarian regime, hatred and cruelty.

Some critics, including those living outside the Soviet Union (L. Senyk, I. Zub, B. Kravtsiv and others), supported E. Gutsalo, calling him "the originator of new modern prose", while others condemned the artist's work and the prose writer was accused of "ambiguity of artistic design" (L. Bahayev), asociality of works (V. Andrienko).

Key words: sixties novelist, psychologism, personification, allusions, contextual detail, social realism, "Dnipro" magazine.

Постановка проблеми. До чільних прозаїків літературного шістдесятництва належать такі письменники як Є. Гуцало, В. Дрозд, В. Шевчук та інші. Увагу до себе вони привернули насамперед новелами та оповіданнями, опублікованими на сторінках «Літературної газети» 23 січня 1962 року. У наступні роки ці письменники зверталися до різних жанрів, висвітлювали актуальні тогочасні проблеми, осмислювали внутрішній світ героя, не завжди дотримуючись настанов і догм соцреалізму, що свідчило про те, що в українській літературі з'явилися митці з власним ідіостилем та художньо-естетичними пошуками в різних стильових напрямах. Дослідження творчості цих митців, зокрема Є. Гуцала, дасть змогу краще усвідомити літературний процес того часу, що свідчить про актуальність цієї теми.

Аналіз досліджень дає змогу говорити про наявність невеликої кількості робіт на цю тематику. Окремі аспекти зазначеної проблематики осмислювали літературознавці й критики Л. Громик, Н. Мирщук, Л. Тарнашинська, О. Подлісецька, В. Фащенко, О. Чепурна та інші. Однак загальний огляд прозових творів $Є$. Гуцала, опублікованих у журналі «Дніпро» всередині минулого століття, ще не ставав об'єктом грунтовних наукових розвідок, тому вважаємо, що таке дослідження на часі.

Мета статті - проаналізувати прозові твори Є. Гуцала, опубліковані всередині минулого століття в журналі «Дніпро», осмислити психологізм творів та особливості ідіостилю письменникапочатківця.

Виклад основного матеріалу. На початку своєї творчості письменники-шістдесятники здебільшого зверталися до малих прозових форм, оскільки «роман як втілення діалогічних структур художньої свідомості народжується тоді, коли автор дозріває вступити у відкритий діалог із суспільством. Натомість монологічна тональність новели $\epsilon$ потребою здебільшого «внутрішньої розмови» (Тарнашинська, 2005: 408). Новелістика, крізь призму якої вони прагнули «показати великі людинознавчі проблеми» (Тарнашинська, 2005: 409), відігралаважливу роль іу творчості шістдесятниківпрозаїків, і в розвитку великих жанрів.
У коротких прозових формах, насамперед у новелах та оповіданнях, ці літературні новобранці прагнули осягнути й відтворити внутрішній стан свого героя 3 його інтимними думками та переживаннями, натомість офіціоз вимагав від авторів акцентування на соціальній проблематиці, ідеологічно інтерпретованій. Не дивно, що й реакція на цю прозу була різною. Якщо одні письменники й критики в Україні (П. Загребельний, С. Крижанівський, Л. Новиченко, М. Рильський) загалом підтримали пошуки літературних дебютантів, якщо на емігранта Б. Кравціва від їхніх творів «повіяло свіжістю, оригінальністю, новизною» (Кравців, 1962: 51), то Л. Дмитерко, реагуючи на зміну назви «Літературної газети» на «Літературну Україну», несхвально відгукнувся на низку творів молодих літераторів і певні критичні статті, опубліковані в «Літературній газеті». Він висловив переконання, що їх «не слід брати у спадщину, а ліпше залишити перед брамою «Літературної України» (Дмитерко, 1962: 4).

За спостереженнями дослідників, на формування світогляду та морально-естетичних цінностей $Є$. Гуцала вплинули усна народна творчість, художній досвід класиків (М. Коцюбинський, М. Рильський, М. Стельмах), родина та «дух епохи 3 ії глобальними конфліктами» (Бульбачинська, 2017: 48). Є. Гуцало зумів створити оригінальний лірико-романтичний, лірико-психологічний стиль, основу якого склали «тонка акварельна манера письма, дитинна чистота і ясність світовідчуття, відкритість ліричного героя до прекрасного в усіх його виявах», увага «до народних характерів, інших національних прикмет - вічних і нових» (Жулинський, 1994: 198).

Пізніше сам автор погоджувався із цим: «Принцип лірико-романтичного осягнення людини i світу» колись найбільше відповідав моїй удачі, виражав психіку, емоції, тому-то він і знайшов реалізацію в багатьох (особливо у кращих) моїх творах» (Жулинський, 1994: 198). Є. Гуцало уточнював, що на зміну «лірико-поетичному етапу» (збірки «Яблука з осіннього саду», «Скупана у любистку», «Серпень, спалах любові») у його творчості прийшов спочатку «суто реалістичний» етап (повісті «Мертва зона», «Родинне вогнище», «Сільські вчи- 
телі», «Шкільний хліб», «Подорожні»), а згодом і «химерно-гротескний» (роман-трилогія «Позичений чоловік», «Приватне життя феномена», «Парад планет») (Жулинський, 1994: 198).

Новелістика С. Гуцала 1960-1970-х років представлена «найрізноманітнішими видозмінами новелістичної форми: настроєвий етюд, пейзаж, поезія у прозі, ліричний монолог-медитація, розгорнуте сюжетне оповідання» (Дончик, 1994: 56), «просякнута натурфілософським світобаченням» (Тарнашинська, 2018: 415).

Письменник розповідав: «Природа завжди вабила мене, завжди мала вплив на душу й відгук у душі, і цей її вплив і відгук були для мене важливі й потрібні. Природа - один із героїв мало не всього того, що я написав» (Гуцало, 2008: 25). Часто вона була виразно імпресіоністична, оскільки в ній «наявні зображення таємничого відчуття, яке важко описати, ліризм оповіді та особливий поетичний стиль, який називають «секундним» (Подлісецька), «природність буття у всьому багатстві його подробиць і проминальних, але важливих для людини станів» (Фащенко, 2005: 508), «одномоментність показу пейзажу та відповідного душевного стану героя, [...] подолання статики зображення, акцентуація на мінливості дійсності» (Подлісецька), нерідко фрагментарне відтворення дійсності й думок героїв, а «образ оповідача часто ідентифікується 3 ліричним героєм i самим автором; їх пов'язує єдність місця, де протікає дія, і єдність настрою» (Мирщук, 2001: 36).

Є. Гуцало відразу зарекомендував себе і талановитим, і плідним письменником. Протягом 1960-х років побачили світ його збірки оповідань «Люди серед людей», «Яблука 3 осіннього саду», «Скупана в любистку», «Хустина шовку зеленого», «Запах кропу», схвально зустрінуті як читачами, так і фахівцями. Так, на його дебютну збірку доброзичливо відгукнулися і авторитетний письменник П. Панч зі статею «Молодий голос» у московському часописі «Дружба народов», і молоді критики Л. Сеник та І. Зуб, і Б. Кравців, який назвав $€$. Гуцала «зачинателем нової модерної прози» (Кравців, 1962: 59).

Однак висловлювалися й інші оцінки. У лютому 1969 року на пленумі СПУ Є. Гуцала і його колег Д. Павличка та В. Дрозда звинувачували в аполітичності, ідейній незрілості й формалізмі. В. Андрієнко наголошував на асоціальності творів С. Гуцала, який «не пише ні виробничі, ні перевиховні оповідання: для цього він надто художник» (Андрієнко, 1965: 150). Ю. Бадзьо закидав письменнику брак «життєвого джерела таланту; певної культурно-психологічної атмос- фери, соціальної характеристичності у мисленні та почуваннях людей» (Бадзьо, 1970: 159), а Л. Бахаєва - «аморфність авторської ідеї, неясність художнього задуму» (Бахаєва, 1973: 175). В академічній «Історії української літератури» констатували, що перед письменником стоїть «проблема більш рішучого і впевненого виходу у світ соціальних питань і взаємозв'язків, поширення ідейного діапазону своєї творчості», йому радили включити «у коло своєї обсервації переживання й емоції, пов'язані $з$ працею, з відносинами людей у колективі, з різними проблемами суспільного життя» (Історія, 1972: 426).

Особливо послідовними у критиці $Є$. Гуцала були Л. Санов і М. Шамота. Останій, як згадував письменник, оцінюючи повість «Двоє на святі кохання», «сичав, що я стою не на тих платформах, тобто не на «наших» (Гуцало). Відповідаючи своїм опонентам, він риторично запитував: «Чи треба аж стільки кидати каміння у письменників, які порятувалися з газових печей соціалістичного реалізму, з крематоріїв мистецько-філософських догм, із цього страхітливого комплексу смертельної чорнобильської естетики?» (Гуцало).

Плідні творчі стосунки склалися у Є. Гуцала 3 редакцією журналу «Дніпро». Цьому посприяв М. Руденко, який у 1947-1950 роках працював головним редактором журналу. Письменник згадував: «Микола Руденко прочитав мої перші оповідання і допоміг їх опублікувати в журналі «Дніпро». Це був дебют із чотирьох оповідань. Та ще й рекомендував мою першу книжку видавництву «Молодь», в якому у 1962 році побачили світ мої «Люди серед людей» (Гуцало). Він мав на увазі оповідання «Дума про Овлура», «Гордій», «Розлилися круті бережечки», «Припутень», які були видрукувані у 8 номері журналу за 1961 рік.

За наступні десять 3 лишком років у цьому журналі побачили світ близько 20 різножанрових творів С. Гуцала, у тому числі три повісті. У них письменник прагнув осмислити соціально-побутові проблеми тогочасного суспільства (повісті «Передчуття радості» i «Бузок у рядні», оповідання «Розлилися круті бережечки»), осягнути внутрішній світ особистості й відтворити дитячі відчуття і враження (оповідання «Уночі», «Припутень», «Сльози землі», «По колоски», «Рідні», «Мельник і його дочка», «Проти Івана сонце іграло», повість «У гаї сонце зацвіло»), змалювати зародження перших почуттів (новела «Верхи через луги та поля»), показати жахіття війни (оповідання «Брат і сестра», «Дума про Овлура», «У полях», «Дорога 3 дитинства») і труднощі повоєнних буднів (повість «Родинне вогнище»). 
Свого часу Б. Кравців, хоча і високо оцінював творчість С. Гуцала, зауважив, що в оповіданнях «Дума про Овлура», «Гордій» і «Розлилися круті бережечки» $\epsilon$ ще «багато початківського, писані вони в панівному для радянської прози річищі 3 лакуванням дійсности і героїв, вони не відбігають далеко від загального тону радянської прози» (Кравців, 1962: 59). Ці твори прозаїка-дебютанта справді писалися під неуникним впливом соцреалістичного методу, однак у них вже проглядалося авторське прагнення до пошуку нових підходів у зображенні людини і дійсності.

Так, головний герой оповідання «Дума про Овлура» зображений як особистість винятково позитивна та цілеспрямована. Він своїм прикладом зумів залучити інших до будівництва дороги. Однак наявна в оповіданні містка метафора дороги трансформується, як слушно зауважила Л. Тарнашинська, «в метафору власноруч прокладеної бруківки як мрії про краще життя, яка працює на авторську концепцію людського життя як «власноручну» творчість, повернуту «обличчям» до джерел. Сила громади може бути активізована й піднята до рівня творчості зусиллям однієї людини - ось провідна думка письменника» (Тарнашинська, 2017: 20).

У цьому творі $€$. Гуцало широко використав алюзії на «Слово про похід Ігорів», нагадавши про трагізм усіх воєн, незважаючи на час, коли вони відбувалися: «Дорога простягалася від одного села до іншого... Оповідають, що на ii місці за незапам'ятних часів була річка [...]. Та потім річка пересохла, а по пї руслу люди протоптали стежку. I це полегшило напад половцям [...]. Вони зруйнували городище, до ноги винищили полянів, пощадивши лише тих, хто не дістав до луки і сідла, не носив меча і не міг відомстити кров'ю ворогів за кров рідних» (Гуцало, 1961: 64).

Не оминув автор і трагічної теми братовбивства, оскільки нерідко родичі боролися в лавах непримиренних ворогів. Так, в Овлура було два сини, протилежність політичних принципів яких позначилася на їхній подальшій долі: «У ту війну, від кінця якої пішов уже другий десяток літ, молодший син подався в партизани. Його зеленим домом був Чорний ліс. Старший залишився в селі. Він став поліцаєм. I час звів разом двох братів. Старший утікав по дорозі. Він біг мимо батьківської хати, в якій уже не жив давно: батьки відцуралися від нього, а він від них, [...] утікач відчував, що повітря перепиняє йому шлях, стаючи важкою непрохідною стіною, а земля чіпляється до ніг і не пускає» (Гуцало, 1961: 66).
Оповідання вражає глибоким психологізмом, зануренням у внутрішній світ героїв. Водночас автор вдається до персоніфікації й імпресіоністичних замальовок, коли відтворює різні події та настрої персонажів у тісному зв'язку з явищами природи: «На обличчі землі дорога лежала великою страдницькою зморшкою. Видно, що багато було зв'язано з нею горя і журби, бо вона навівала сум. Радісною видавалася не часто» (Гуцало, 1961: 64).

Життя Гордія в однойменному оповіданні показане через роздуми персонажа й спогади про партизанщину, одруження, народження сина й убивство дружини Галини, яка доносила німцям на свого чоловіка та його загін. Авторову аргументацію її жаских учинків витримано цілком у дусі теорії класової боротьби, мовляв доносами Галина мстилася за батька, якого «дядьки у двадцятому кокнули. За землю, звичайно. Мав іiі до біса і зубами стояв за добро» (Гуцало, 1961: 71). Перед смертю дружина розкрила всю правду: «... мало ще вас виздихало, ... усіх таких, як ти ... хотіла я б видушити. Це ж ви мого батька порішили, забрали в нашої сім’ї землю й свободу. Голота! Злидарі! Все своє життя я ненавиділа вас, а тебе - найдужче» (Гуцало, 1961: 72). Така побудова твору дає змогу читачам крізь внутрішній стан героя глибше усвідомити пріоритети й принципи автора. Важливим тут $є$ не опис зовнішності Гордія Степановича, а зображення його почуттів, настроїв і ставлення до різних подій.

М. Жулинський зауважив, що письменник «зображує ситуації не завжди соціально місткі, переважно морально-етичного змісту; їх вияв здійснюється іноді на периферії соціальних зв'язків і обставин, але висновки розпросторюються на загальну суспільну атмосферу щоденного життя» (Жулинський, 1986: 9).

На підтвердження цієї думки можна навести оповідання «Розлилися круті бережечки», у якому прозаїк розмірковує над проблемою добра і зла. Фабула твору проста: хлопець Їгон виходить i3 тюрми («в колгоспі телицю вкрав» (Гуцало, 1961: 74), приходить до діда Мирона $з$ проханням перевезти його через річку, бо ж «крига нарічці йде» (Гуцало, 1961: 75). Спочатку дід хотів відмовити парубкові, але все ж погодився виконати його прохання. Їгон не забув дідової доброти й за деякий час повернувся, щоб запросити його на своє весілля.

Через роздуми діда Мирона письменник показує, що існують різні типи людей - добродушні й злопам'ятні. Нерідко вчинок якоїсь людини може вплинути на іншу й навіть до певної міри змінити чийсь характер: «Дід став мислити, що яке то 
життя чудернацьке, які то люди іноді незрозумілі. Буває, за зло ще більшим злом оддячують. А $є$ так, що за зло добром платять, бо інакше зробити не дозволяє їм совість» (Гуцало, 1961: 79). Варто наголосити, що образ діда Є. Гуцало подає відповідно до його традиційного трактування, саме тому дід постає як мудрий, досвідчений чоловік.

Б. Кравців, проаналізувавши твір «Припутень», зауважив, що Є. Гуцало «виявив себе майстром психологічної, в імпресіоністичному жанрі новели» (Кравців, 1962: 54). У ній автор звернувся до теми дитинства, яке відтворив як цілком інший світ, ще сповнений доброти, щастя та великих мрій, навіть попри всі ті негаразди, яких зазнали діти. У творі йдеться про сільських дітей і їхній «похід» проти «безбатченків», «близнюків і пуцвіріньків» (Гуцало, 1961: 81) Бориса й Ірки. За авторським творчим задумом непорозуміння між дітьми минає тоді, коли вони починають годувати голубів і милуватися ними, особливо припутнем, який «не лякається. Випнувши гордовито грудки, він повагом ходить, подзьобує кришки» (Гуцало, 1961: 81). За твердженням Б. Кравціва, твір написано «без притаманної іншим радянським оповіданням цього типу ідеалізації - підсолоджування сільського життя, із доброю спостережливістю і відчуттям реальности й гумору» (Кравців, 1962: 59).

У 1962 році в журналі «Дніпро» було опубліковане оповідання «У полях», в якому оповідач підкреслено беземоційно згадує своє тяжке «повоєнне дитинство» (Гуцало, 1962: 76), коли 3 війни «поверталися батьки» (Гуцало, 1962: 76), коли і в мирний час ця війна озивається новим болем, новими солдатськими трагедіями. Одна 3 них пов'язана 3 долею Степана Галайди, «славного здоров'яка, широколицого співуна» (Гуцало, 1962: 77), який після повернення додому застав матір із відірваною рукою й спалену хату. Солдат, який «неушкодженим» пройшов усю війну й зазнав чимало горя, гине вже в мирному житті, підірвавшись на міні, коли «орав поле, де не ходив плуг ще з сорок першого року» (Гуцало, 1962: 79).

Трагічно склалася і доля Семена, який повернувся до рідного села з війни й довідався, що його молода дружина збожеволіла після помилкової звістки про загибель коханого: «Чоловіка забрали на війну, а скоро й сповіщення надійшло. Мовляв, пропав без вісти. Галька тільки зойкнула, коли почула про це. Замкнулася в хаті на тиждень, а коли з'явилася перед людьми, то вже несповна розуму була» (Жулинський, 1986: 79).

В оповіданні показано розруху, постійний голод i безвихідність становища тогочасних людей: «Ми голодні, босі, обідрані [...]. Найчастіше доводилося ласувати квасцем. Визбирували його в лісі, в лузі; оскому набивали таку, що самі собі беззубими здавалися. А після денної ходанини та біганини на нас чекала юшка: на цілий казан кришилося кілька картоплин, така-сяка затируха, а решта - гичка бурякова. Через те голодне їдло мали животи великі, як турецькі барабани» (Гуцало, 1962: 77). Своїми правдивими картинами руйнівних наслідків війни оповідання виразно дисонувало 3 піднесеним, переможним настроєм багатьох тогочасних творів на цю тему.

Для глибшого увиразнення ідеї твору автор вдався до концептуальної деталі - гармати, яка $\epsilon$ символом війни, розрухи та численних смертей: «Середсивихполинів-гармата.Мовчазна,похмура, чорна. Не наша. Задерла жерло в чисте небо, націлилася в його голубе свято» (Гуцало, 1962: 77).

У повісті «Бузок у рядні» $Є$. Гуцало створив образ дівчини Галі, передав їі роздуми, пов'язані зі школою, першим коханням і ставленням до різних людей і подій. Галя та іiі мати Настя - дуже романтичні натури, доброзичливі і мрійливі, тому вони не завжди здатні порозумітися з іншими людьми, через що й виникає певний душевний конфлікт.

Під час війни Настя переховувала солдата Панюка, у якого закохалася, а тому часто згадувала його: «Вона [...] ніяк не могла визначити, що ж воно таке і для чого вона народилася на білий світ - чи для того, щоб згадувати минуле, відводячи йому у своєму єстві все більше місця, чи для того, щоб чекати на завтрашній день i, дочекавшись його, побачити, що і в ньому те минуле, отой важкий на ласку Панюк займає все більше місця, хоча він віддаляється далі й далі» (Гуцало, 1963: 68), бо ж «люди зацвітають, як дерева, як поля, з чимось борються - 3 вітром, з бурею і вічно пливуть до берега щастя» (Гуцало, 1963: 68).

Настя працювала в колгоспі, і коли розповідала про свою роботу, то повторювала «звичні, знебарвлені слова, які давно втратили для неї свій запах, первісну незвичність» (Гуцало, 1963: 65). Єдине, у чому Настя бачила сенс життя, - ¥ї дочка Галя, яка, як здавалося матері, завжди поруч: «Усі люди - це велике дерево. А малесенькі гіллячки це ти, я, всі люди. Одна гілка другу добре відчуває. А ти - моя дочка. Зі мною так іноді буває [...] роблю на фермі, біля свиней ходжу, аж раптом посвітліє в мені, і вже ніби я не в свинарнику, а 3 тобою в школі, і вже ніби й не з тобою, а ти - це я» (Гуцало, 1963: 72).

Галя закохана в свого однокласника Славика, який багато читає і навіть «музику хоче зрозуміти» (Гуцало, 1963: 78). Хлопець і дівчина 
схожі за своїми характерами: для них головними $\epsilon$ не матеріальні блага, а духовний спокій і гармонія. Так, попри непереборне бажання придбати нову сукню, Галя відмовилася продавати бузок із тих кущів, які посадила раніше, бо ж саме біля них дівчина нерідко проводила час і тільки цим мовчазним слухачам довіряла свої найпотаємніші думки. Автор уводить до повісті прийом сну, який дозволяє показати різні періоди в житті Галі, зобразити ставлення дівчини до одних і тих же подій у 4 роки й у підлітковому віці.

Тему війни письменник розкриває через усвідомлення іiї як страшного лиха, яке приносить розруху та голод: «... як ми жили в чорній сирій землянці, а зі стелі капала вода, коли йшов дощ [...]. А потім ми гралися патронами, [...], а ще мама плакала ночами - тихенько плакала, думала, що я не чую. Вона журилася, бо в нас не було хліба і доводилося їсти лободу в окропі» (Гуцало, 1963: 74).

У повісті автор вдається до різних форм нарації, зокрема до форми сну, оповіді від автора та від різних героїв. Використання цих наративних прийомів дозволило митцеві змістити часові площини, відтворити події різних років і зобразити ставлення окремих людей до різних подій. Для підсилення психологізму твору, увиразнення внутрішнього світу героїнь та їхніх думок письменник звертається до персоніфікації: «Бузки пам’ятають, як одного вечора сюди прийшла Настя [...]. Бузки те все запам'ятали. I вони зіщулилися від холоду та від болю, їм було самотньо та гірко, не менше, ніж Насті, але вони не були людьми, не вміли ні говорити, ні співчувати. Вони розуміли тільки самі себе, обходилися своїми бузковими словами, бузковими почуттями, бузковою любов'ю, але не вміли і не могли перенести ті почуття на людей» (Гуцало, 1963: 64).

В оповіданні «Мельник і його дочка» $С$. Гуцало зобразив конфлікт між духовно багатою Марійкою, дочкою мельника, яку ще не зачепили жодні життєві невдачі та проблеми, і довколишнім світом. Дівчинка любить проводити час біля батькамельника, тому «вона ніби зеленоокий дух цього підстаркуватого колгоспного млина» (Гуцало, 1964: 48). Марійка відчуває гармонію $з$ природою, вона романтична, доброзичлива, лагідна та щира, останнє яскраво засвідчено алюзіями на казку про Івасика-Телесика: «Івасику-Телесику, приплинь-приплинь до бережка!» (Гуцало, 1964: 47), однак «Телесик не припливав до бережка, а гусигусенята не брали Марійку на крилята» (Гуцало, 1964: 50). Проте інші сільські діти не розуміють Марійки, її високих поривань і незвичних думок, нерідко однолітки насміхаються з неї.
За твердженням О. Чепурної, для Є. Гуцала дитинство - це «інший, принципово відмінний від дорослого світ, а тому більш досконалий. Він протиставлений дорослому світові як радість / розчаруванню, мрія / буденності й безпосередньо пов'язаний із періодом щастя» (Чепурна, 2008: 16).

Важливу роль у творі відіграють зорові та слухові деталі як елементи імпресіоністичної поетики, які підкреслюють романтичність Марійки. Так, дівчина любить слухати, як «співає вода» (Гуцало, 1964: 49): «Під дошками, зовсім близько, солодко жебоніла вода. Іноді вона наче схлипувала, а потім іiі звук ставав чистий, пронизливо тоненький. Далі він набрякав, уже був соковитий, наливався мелодійною гучністю, доки знову не стишувався. Вода співала сама собі, заслуховувалась своєю прихованою піснею, і гадки не мала, що хтось зараз причастився до ії таємниці» (Гуцало, 1964: 50). У наведеному уривку відсутні описи роздумів дівчини, замість них відтворено враження та почуття героїні. Саме тому творові притаманний ліризм оповіді, психологічне напруження, пов'язане 3 непорозумінням із дітьми, певна ритмічна організація тексту. Це оповідання витримане в дусі неореалізму у поєднанні 3 такими ознаками імпресіоністичного стилю як звукові та слухові деталі, персоніфікація природи, ліризм оповіді й передача почуттів персонажа.

До дитячої тематики звернувся $Є$. Гуцало й у новелі «Проти Івана сонце іграло». За сюжетом твору школяр Сергійко вирішив скоротити шлях до школи і перейти через річку під час льодоходу. Під час перебування на льоду сили та наснаги хлопцеві додавала пісня матері, яку вона неодноразово йому співала: «Гусята, качата / Гречечку з'їли, / На панів ставочок / Питки злетіли. / Ой у сінях, / За дверечками, / Стоїть ліжечко / 3 подушками. / На тім ліжечку / Іванко сидить, / На правій руці / Скрипочку держить...» (Гуцало, 1964: 57). Автор невипадково увів до твору рядки з пісні, акцентуючи увагу на важливості утримувати зв'язок із рідною землею і традиціями свого народу: «Хлопець вбирав у себе пісню, наповнювався нею по вінця, як кухоль наповнюється водою, і та пісня, вперше чута, звучала для нього знайомо, відкривала небачене, яке здавалося давно баченим, тільки забутим» (Гуцало, 1964: 57).

Оповідання «Криниця» також характеризується простою фабулою: дівчині Рузі не вдалося принести додому води 3 криниці через веселощі хлопців, які збивали іiі з ніг: «Рузя, палаючи від сорому, від незаслуженої кривди та й ще від чогось, чого й сама не могла второпати, хутко подалася додому» (Гуцало, 1964: 54). Авторові важливіше 
відтворити не події, а внутрішній світ дівчини, ï настрій і думки. 3 одного боку, дівчина засмучена і збентежена, проте з іншого - вона щаслива, бо закохана в одного 3 тих, хто заважає їй виконати повсякденну роботу: «Під березами сміялись. Але так, ніби мали якусь свою причину для сміху, а того, що скоїлося з Рузею, не помітили. Дебелий Сивокінь реготав найдужче, i його густий голос аж порипував од своєї сили» (Гуцало, 1964: 53).

Почуття головної героїні яскраво підкреслюють персоніфіковані предмети і явища природи: «У моїй пам'яті виникає зимова вулиця. Вона сумна й сива, як стара жінка. Вона задумалася, але ії задума не важка, а напрочуд легка, окрилена 3 обох боків крилами городів, окрилена заметеними стріхами» (Гуцало, 1964: 52). Так і Рузя, яка постійно думає про вподобаного юнака, стає надзвичайно загадковою, бо ж намагається нікому не зрадити своїх почуттів.

Подібні твори були новим явищем в українській радянській літературі, оскільки в них авторська увага зосереджувалася на внутрішньому світі людини, а не на іiі соціально-виробничій сфері. Їх важливими рисами стали ліризм, взаємодія людини й природи, внутрішні роздуми, відтворені в монологах і діалогах персонажів. Як бачимо, зв'язок зі своєю землею, із традиціями та фольклором дає наснагу, радість і бажання жити. Письменники-шістдесятники неодноразово наголошували на необхідності національного та духовного відродження суспільства.

На думку Л. Громик, стилю «реалістичної прози $€$. Гуцала властивий високий рівень правдивості щодо відтворення письменником прикмет часу i життєвих реалій, ... психологічне портретування, психологічний пейзаж, зовнішне та внутрішне мовлення, конструювання людських характерів у вчинках, здійснених у межових ситуаціях чи певному психоемоційному стані, взаємозв'язок внутрішнього світу людини з навколишнім простором, відтворення в моральній позиції ії людської сутності, в художній деталі - іiї психології» (Чепурна, 2008: 5).

Подібним чином можна охарактеризувати й повість «Родинне вогнище», у якій автор крізь внутрішній світ жінки, ії світобачення та психологію «розгортає об'єктивно-реалістичну картину повоєнного буття українського народу, відтвореного в широкому діапазоні соціальної, ментальнопсихологічної та морально-етичної проблематики, розмірковує «про драматизм і висоту материнської місії» (І. Дзюба)» (Чепурна, 2008: 8). Вона ідейно опонувала багатьом тодішнім творам про «щасливе колгоспне життя».
Є. Гуцало зазначав, що «найвизначальнішим етапом у моєму житті слід вважати другу половину шістдесятих років, коли написав повісті «Мертва зона», «Родинне вогнище», «Сільські вчителі», «Подорожні», які відношу до об'єктивної, реалістичної прози» (Жулинський, 1994: 158).

Спочатку повість 3'явилася у журналі «Дніпро» в скороченому варіанті, а згодом вона увійшла до збірки повістей під назвою «Мати своїх дітей», де, за твердженням автора, виявилася далекою «від первісного задуму» (Жулинський, 1994: 158).

Головна героїня повісті - Ганка Волох, яка втратила на війні чоловіка й відтоді сама виховує трьох дітей. У ній автор «продовжує національну літературну традицію творення жінки-матері як великої страдниці та невтомної трудівниці» (Чепурна, 2008: 8). С. Гуцало зобразив Ганку як люблячу маму («в мене цих дітей троє, але кожне дороге, за всякі гроші дорожче» (Гуцало, 1968: 29a), гарну домогосподарку, яка працювала не лише вдома, а й у колгоспі, ще й сторожем у магазині («вдень Ганка добувалася в ланку, орудувала сапою чи заступом, а коли треба, то й серпом; увечері, наморена, ніг під собою не чуючи, поверталася додому, готувала вечерю для дітей i, з'ївши що-небудь, а то і не з'ївши, бо не завжди кусок і в горло ліз, ішла до сільмагу» (Гуцало, 1968: 71a).

Жінка без чоловіка не тільки виховує дітей, а й усіляко намагається відновити господарство, зруйноване під час війни. Ганка дуже горда, чесна та справедлива («не брала чужого й не візьму» (Гуцало, 1968: 36а). Незважаючи на складне життя, своїм дітям матір прищеплює високі моральні цінності. Саме тому, коли їі син украв мішок картоплі, Ганка змусила його повернути поцуплене власникові («вмів украсти, хай уміє й віддати. Хіба вона вчила його брати в людей? Хіба вона сама коли-небудь потягнула чуже? Не було такого й не буде, хай навіть як важко не доводиться» (Гуцало, 1968: 38b).

Можна стверджувати, що Ганка Волох - це узагальнений образ виснажених працею жінок-матерів, на плечах яких у післявоєнний час трималися діти й усе господарство. Автор невипадково назвав твір саме «Родинне вогнище». Це поняття набуває глибокого сакрального звучання й символізує високу місію жінки - за будь-яких умов і життєвих обставин зберегти рід, бути вправною господинею, ростити дітей, захищати й втілювати у життя вироблені народом морально-етичні принципи.

У «Родинному вогнищі» автор описує й українські народні традиції, зокрема у повісті зображено обряд вигнання нечисті з людей («шептуха 
виганяла із Сані злий дух. Качала яєчко на голові, навколо голови, грудей, спини, навколо рук, ніг» (Гуцало, 1968: 38b); толоку, яка викликала в Ганки суперечливі думки: $з$ одного боку - усвідомлення свого щастя, а 3 іншого - розуміння того, що до нової хати все ж «переселиться тінь твого скупого щастя, твоєї гіркоти» (Гуцало, 1968: 45b). Згадує прозаїк і про християнське свято Великодня, пише про церкву, яку в Збаражі «рознесли під час колективізації» (Гуцало, 1968: 16b), уводить назви пісень, які свідчить про щиру прив'язаність митця до рідної землі, про усвідомлення письменником важливої місії народних традицій і звичаїв у житті кожного індивіда.

Висновки. Є. Гуцало, як і інші письменникишістдесятники, творив в умовах жорстких догм i шаблонів соцреалізму. Звичайно, це позначилося на окремих його творах, особливо на перших пробах пера. Однак письменник спромігся всупереч ідеологічній несвободі у своїй лірико-романтичній, а потім і реалістичній прозі давати правдиві картини життя народу за часів радянської влади, відстоювати загальнолюдські цінності, глибоко розкривати внутрішній світ сучасника.

Персонажами його творів є люди різного віку, проте особливу увагу він приділяв дітям, крізь свідомість яких можна по-іншому подивитися на світ, спотворений тоталітарною системою. Домінантними рисами доробку письменника $є$ ліризм, психологізм, контекстуальна деталь, дегероїзація прози, персоніфікація та сприйняття природи як органічної частини життя людини.

\section{СПИСОК ВИКОРИСТАНИХ ДЖЕРЕЛ}

Андрієнко В. Стверджувати - це відкривати. Дніпро. 1965. № 9. С. 139-152.

1. Бадзьо Ю. Пора перших підсумків. Вітчизна. 1970. № 1. С. 159-167.

2. Бахаєва Л. До питання про сюжети. Вітчизна. 1973. № 4. С. 167-175.

3. Бульбачинська О. Творчість Євгена Гуцала: естетичні засади. Синопсис: текст, контекст, медіа. 2017. № 3. C. $45-58$.

4. Громик Л. Повісті Євгена Гуцала: морально-етична проблематика і поетика : автореф. дис. канд. філолог. наук: 10.01.01. Чернівці, 2011. 22 с.

5. Гуцало Є. Бузок у рядні. Дніпро. 1963. № 6. С. 60-84.

6. Гуцало Є. Дума про Овлура, Гордій, Розлилися круті бережечки, Припутень [Thought of Ovlura, Gordian, Spilled steep banks, Priputen]. Дніпро. 1961. № 8. С. 64-82.

7. Гуцало Є. Мельник і його дочка, Криниця, Проти Івана сонце іграло. Дніпро. 1964. № 12. С. 47-59.

8. Гуцало Є. Родинне вогнище. Дніпро. 1968. № 2. С. 42-92.

9. Гуцало Є. Родинне вогнище. Дніпро. 1968. № 3. С. 13-50.

10. Гуцало Є. У полях. Дніпро. 1962. № 3. С. 76-81.

11. Гуцало Є. Чому весь час до Бога знімається рука? Незалежний культурологічний часопис «Ï̈». URL: http://www.ji-agazine.lviv.ua/Promovy_laureativ_premii_Antonovychiv /Hutsalo.htm.

12. Дмитерко Л. 3 новою назвою - до нових висот. Літературна Украӥна. 1962. 16 лют. С. 4.

13. Жулинський М. Лірична стихія творчості Євгена Гуцала [Lyrical element of Yevhen Gutsal's work]. Украӥнське слово. Т. З. К., 1994. 688 с.

14. Жулинський М. У передчутті радості. Наближення: літ. діалоги. К., 1986. С. 91-121.

15. Історія української літератури XX століття : навч. посіб. для студ. філол. ф-тів вищ. навч. закл.: у 2 т. Кн. 2, ч. 2: 1960-1990-ті роки / ред. В. Г. Дончик. К., 1994. 510 с.

16. Історія української літератури: у 8 т. / редкол.: Д. Т. Вакуленко та ін. К., 1972. Т. 8: Література післявоєнного часу (1946-1967). $571 \mathrm{c}$.

17. Кравців Б. До синіх зір. Сучасність. 1962. № 8 (20). С. 50-67.

18. Мирщук Н. Мала проза Є. Гуцала: поетика жанру : монографія. К., 2001. 148 с.

19. Подлісецька О. Імпресіоністичні тенденції у неореалістичних новелах $€$. Гуцала та А. Колісниченка. URL: http://liber.onu.edu.ua:8080/bitstream/handle/123456789/4868/ novel.kolis. pdf;jsessionid=7065714474F18E426D6089A69 E0B5D5A?sequence $=1$.

20. Тарнашинська Л. Антропологічні практики повсякдення: людина як психологічна цілісність. Слово $i$ час. 2017. № 1. C. 18-22.

21. Тарнашинська Л. «Нова епічність» VS лжеепічність: проекція творчості українських шістдесятників на світові процеси. Сучасні мово- $і$ літературознавчі методології та нові прочитання художнього тексту. Луцьк, 2018. C. $413-427$.

22. Фащенко В. У глибинах людського буття. Літературознавчі студії. Одеса, 2005. 640 с.

23. Чепурна О. Дискурс дитини у прозі українських письменників-шістдесятників (Гр. Тютюнник, В. Близнець, Є. Гуцало) : автореф. дис. канд. філол. наук: 10.01.01. Кіровоград, 2008. 24 с. 


\section{REFERENCES}

1. Andriienko V. Stverdzhuvaty - tse vidkryvaty [To assert is to discover]. Dnipro. 1965. № 9. P. 139-152 [in Ukrainian].

2. Badzo Yu. Pora pershykh pidsumkiv [It’s time for the first results]. Vitchyzna. 1970. № 1. P. 159-167 [in Ukrainian].

3. Bakhaieva L. Do pytannia pro siuzhety [To the question of plots]. Vitchyzna. 1973. № 4. P. 167-175 [in Ukrainian].

4. Bulbachynska O. Tvorchist Yevhena Hutsala: estetychni zasady [Creativity of Yevhen Gutsal: aesthetic principles]. Synopsys: tekst, kontekst, media. 2017. № 3. P. 45-58 [in Ukrainian].

5. Hromyk L. Povisti Yevhena Hutsala: moralno-etychna problematyka i poetyka [Novellas of Yevhen Gutsal: moral and ethical problems and poetics] : avtoref. dys. kand. filoloh. nauk: 10.01.01. Chernivtsi, 2011. 22 p. [in Ukrainian].

6. Hutsalo Ye. Buzok u riadni [Lilac in the sheet]. Dnipro. 1963. № 6. P. 60-84 [in Ukrainian].

7. Hutsalo Ye. Duma pro Ovlura, Hordii, Rozlylysia kruti berezhechky, Pryputen. Dnipro. 1961. № 8. P. 64-82 [in Ukrainian].

8. Hutsalo Ye. Melnyk i yoho dochka, Krynytsia, Proty Ivana sontse ihralo [Miller and his daughter, Well, The sun was playing against Ivan]. Dnipro. 1964. № 12. P. $47-59$ [in Ukrainian].

9. Hutsalo Ye. Rodynne vohnyshche [Family hearth]. Dnipro. 1968. № 2. P. $42-92$ [in Ukrainian].

10. Hutsalo Ye. Rodynne vohnyshche [Family hearth]. Dnipro. 1968. № 2. P. 42-92 [in Ukrainian].

11. Hutsalo Ye. U poliakh [In the fields]. Dnipro. 1962. № 3. P. 76-81 [in Ukrainian].

12. Hutsalo Ye. Chomu ves chas do Boha znimaietsia ruka? [Why is the hand to God removed all the time?] Nezalezhnyi kulturolohichnyi chasopys "I". URL: http://www.ji-agazine.lviv.ua/Promovy_laureativ_premii_Antonovychiv/Hutsalo.htm.

13. Dmyterko L. Z novoiu nazvoiu - do novykh vysot [With a new name - to new heights]. Literaturna Ukraina. 1962. 16 liut. p. 4 [in Ukrainian].

14. Zhulynskyi M. Lirychna stykhiia tvorchosti Yevhena Hutsala. Ukrainske slovo. T. 3. K., 1994. 688 p. [in Ukrainian].

15. Zhulynskyi M. U peredchutti radosti [In anticipation of joy] Nablyzhennia: lit. dialohy. K., 1986. P. 91-121 [in Ukrainian].

16. Istoriia ukrainskoi literatury XX stolittia [History of Ukrainian literature of the twentieth century] : navch. posib. dlia stud. filol. f-tiv vyshch. navch. zakl.: u 2 t. Kn. 2, ch. 2: 1960-1990-ti roky / red. V. H. Donchyk. K., 1994. 510 p. [in Ukrainian].

17. Istoriia ukrainskoi literatury [History of Ukrainian literature]: u 8 t. / redkol.: D. T. Vakulenko ta in. K., 1972. T. 8: Literatura pisliavoiennoho chasu (1946-1967). 571 p. [in Ukrainian].

18. Kravtsiv B. Do synikh zir [To the blue stars]. Suchasnist. 1962. № 8 (20). P. 50-67 [in Ukrainian].

19. Myrshchuk N. Mala proza Ye. Hutsala [E. Gutsal's short prose]: poetyka zhanru : monohrafiia. K., 2001. 148 p. [in Ukrainian].

20. Podlisetska O. Impresionistychni tendentsii u neorealistychnykh novelakh Ye. Hutsala ta A. Kolisnychenka. URL: http://liber.onu.edu.ua:8080/bitstream/handle/123456789/4868/novel.kolis.pdf;jsessionid=7065714474F18E426D6089A69E0B5D5A? sequence $=1$.

21. Tarnashynska L. Antropolohichni praktyky povsiakdennia: liudyna yak psykholohichna tsilisnist [Anthropological practices of everyday life: man as a psychological whole]. Slovo $i$ chas. 2017. № 1. P. 18-22 [in Ukrainian].

22. Tarnashynska L. "Nova epichnist" VS lzheepichnist: proektsiia tvorchosti ukrainskykh shistdesiatnykiv na svitovi protsesy. Suchasni movo- i literaturoznavchi metodolohii ta novi prochytannia khudozhnoho tekstu. Lutsk, 2018. P. 413-427 [in Ukrainian].

23. Fashchenko V. U hlybynakh liudskoho buttia [In the depths of human existence]. Literaturoznavchi studii. Odesa, $2005.640 \mathrm{p}$.

24. Chepurna O. Dyskurs dytyny u prozi ukrainskykh pysmennykiv-shistdesiatnykiv (Hr. Tiutiunnyk, V. Blyznets, Ye. Hutsalo) [Child's discourse in the prose of Ukrainian writers of the sixties (Gr. Tyutyunnyk, V. Blyznets, E. Gutsalo)] : avtoref. dys. kand. filol. nauk: 10.01.01. Kirovohrad, 2008. 24 p. 